\title{
Mechanism of electron transfer reaction of ternary dipicolinatochromium(III) complex involving oxalate as secondary ligand
}

\author{
HASSAN AMROUN EWAIS ${ }^{\mathrm{a}, \mathrm{c}, *}$ and IQBAL MOHAMED IBRHIUM ISMAIL Ia,b $^{\mathrm{a}}$ \\ a Department of Chemistry, Faculty of Science, King Abdulaziz University, PO Box 80203, \\ Jeddah 21589, Saudi Arabia \\ ${ }^{\mathrm{b}}$ Center of Excellence in Environmental Studies, King Abdulaziz University, PO Box 80216, \\ Jeddah 21589, Saudi Arabia \\ ${ }^{\mathrm{c}}$ Chemistry Department, Faculty of Science, Beni-Suef University, Beni-Suef City, Egypt \\ e-mail: hshalby2002@yahoo.com
}

MS received 21 February 2013; revised 29 April 2013; accepted 27 May 2013

\begin{abstract}
Mechanism of the oxidation of $\left[\mathrm{Cr}^{\mathrm{III}}(\mathrm{DPA})(\mathrm{OX})\left(\mathrm{H}_{2} \mathrm{O}\right)\right]^{-}(\mathrm{DPA}=$ dipicolinate and $\mathrm{OX}=\mathrm{oxalate})$ by periodate in aqueous acidic medium has been studied spectrophotometrically over the $\mathrm{pH}$ range of 4.45-5.57 at different temperatures. The reaction is first order with respect to both $\left[\mathrm{IO}_{4}^{-}\right]$and the complex concentration, and it obeys the following rate law:

$$
d\left[\mathrm{Cr}^{\mathrm{VI}}\right] / d t=k_{6} K_{4} K_{6}\left[\mathrm{IO}_{4}^{-}\right]\left[\mathrm{Cr}^{\mathrm{III}}\right]_{\mathrm{T}} /\left\{\left(\left[\mathrm{H}^{+}\right]+K_{4}\right)+\left(K_{5}[\mathrm{H}+]+K_{6} K_{4}\right)\left[\mathrm{IO}_{4}^{-}\right]\right\} .
$$

The rate of the reaction increases with increasing $\mathrm{pH}$ due to the deprotonation equilibria of the complex. The experimental rate law is consistent with a mechanism in which the deprotonated form $\left[\mathrm{Cr}^{\mathrm{III}}(\mathrm{DPA})(\mathrm{OX})(\mathrm{OH})\right]^{2-}$ is more reactive than the conjugated acid. It is proposed that electron transfer proceeds through an inner-sphere mechanism via coordination of $\mathrm{IO}_{4}^{-}$to chromium(III). Thermodynamic activation parameters were calculated using the transition state theory equation.
\end{abstract}

Keywords. Ternary complex; electron transfer; inner-sphere mechanism; thermodynamic activation parameters.

\section{Introduction}

Pyrdinedicarboxylic acids and their derivatives belong to an interesting series of compounds with biological applications. ${ }^{1}$ Pyrdine-2,6-dicarboxylic acid (dipicolinic acid) is present in nature through oxidative degradation of a product of vitamins, coenzyme and alkaloids and is a component of fulvic acid. It has frequently been cited in literature as a plant sterilizing and water germicidal agent and an antioxidant of ascorbic acid in foods. ${ }^{2}$ Pyrdine-2,6-dicarboxylic acid is almost unique to bacterial spores and may constitute as much as $15 \%$ of their weight. ${ }^{3}$ Dipicolinic acid is a desirable ligand for metal ions because of its low toxicity and amphoteric nature. Niacin or vitamin $\mathrm{B}_{3}$ which is closely related to dipicolinic acid, is precursor of the coenzyme nicotinamide adenine dinucleotide, (NAD) and is required in human diet. ${ }^{4}$ The interaction of transition and heavy metal ions with naturally occurring ligands in living organisms such as dipicolinic acid or its isomers chelidamic acid is

*For correspondence important in evaluating the potential beneficial and deteriorative effect of these ions. Chromium picolinate complex (tris(picolinato)chromium(III)) is currently being used as a food additive and has been shown to assist diabetic patients in maintaining glycemic control. ${ }^{5} \mathrm{Co}$ (II) complex of dipicolinic acid was effective in lowering diabetichyperlipidemia in rats with induced diabetes. $^{6}$

Periodate oxidations have been reported to play an important role in biochemical studies. ${ }^{7,8}$ They are used in the determination of glucose and fructose in invert sugar syrups. ${ }^{7}$ Alpha-amino acids in proteins can be determined by measuring the ammonia produced through oxidation with periodate in alkaline medium. ${ }^{8}$ Also, periodate has been used in the modification of human serum transferrin by conjugation to an oligosaccharide. $^{9}$

The oxidation of chromium from trivalent to hexavalent states is an important environmental process because of the high mobility and toxicity of chromium(VI). ${ }^{10}$ The higher oxidation states of chromium are of interest due to the toxic and mutagenic nature of these oxidation states of chromium. ${ }^{10}$ 
Oxidation of $\mathrm{Cr}(\mathrm{III})$ to $\mathrm{Cr}(\mathrm{V})$ and/or $\mathrm{Cr}(\mathrm{VI})$ in biological systems came into consideration as a possible reason of anti-diabetic activities of some $\mathrm{Cr}$ (III) complexes, as well as of long-term toxicities of such complexes. ${ }^{11}$ Specific interactions of $\mathrm{Cr}$ (III) ions with cellular insulin receptors, ${ }^{12}$ are caused by intra- or extracellular oxidations of $\mathrm{Cr}(\mathrm{III})$ to $\mathrm{Cr}(\mathrm{V})$ and/or $\mathrm{Cr}(\mathrm{VI})$ compounds, which act as protein tyrosine phosphatase (PTP) inhibitors. The current perspective discusses chemical transformations of $\mathrm{Cr}$ (III) nutritional supplements in biological media, with implications for both beneficial and toxic actions of $\mathrm{Cr}$ (III) complexes, which are likely to arise from the same biochemical mechanisms, dependent on concentrations of the highly reactive $\mathrm{Cr}(\mathrm{IV} / \mathrm{V} / \mathrm{VI})$ species, formed in the reactions of $\mathrm{Cr}$ (III) with biological oxidants. ${ }^{13}$

Oxidations of inorganic substrates ${ }^{14,15}$ and some transition metal complexes ${ }^{16,17}$ by periodate are reported to proceed through inner-sphere mechanisms, either labile or inert complexes possessing at least one bridging ligand. Periodate oxidations of the chromium(III) complexes of iminodiacetic acid, ${ }^{18}$ 2-aminopyridine, ${ }^{19} \mathrm{~L}$ $\operatorname{arginine}^{20}$ by periodate were carried out. In all cases, the electron transfer proceeds through an inner-sphere mechanism via coordination of $\mathrm{IO}_{4}^{-}$to chromium(III).

Periodate oxidations of some ternary complexes of chromium(III) and cobalt(II) were investigated. ${ }^{21-24}$ Binary and ternary chromium(III) complexes of uridine involving aspartate as a secondary ligand ${ }^{21}$ by periodate in acid medium were investigated in order to study the effect of secondary ligands on the stability of $\left[\mathrm{Cr}^{\mathrm{III}}(\mathrm{Ud})\left(\mathrm{H}_{2} \mathrm{O}\right)_{3}\right]^{3+}(\mathrm{Ud}=$ uridine $)$ towards oxidation. Kinetics and mechanism of oxidation of the binary and ternary $\mathrm{N}$-(2-acetamido)iminodiacetatocobaltate(II) complexes ${ }^{23,24}$ involving malonate ${ }^{23}$ succinate and maleate ${ }^{24}$ as secondary ligands by periodate have been investigated. In all cases, initial cobalt(III) products were formed, and these changed slowly to the final cobalt(III) products. It is proposed that the reaction follows an inner-sphere mechanism, which suggested relatively faster rates of ring closure compared to the oxidation step.

In this article, the kinetics of oxidation of $\left[\mathrm{Cr}^{\mathrm{III}}(\mathrm{DPA})(\mathrm{OX})\left(\mathrm{H}_{2} \mathrm{O}\right)\right]^{-}$by periodate was studied in order to assume the effect of complex formation on the resistance of chromium(III) towards oxidation and also to deduce the reaction pathways.

\section{Experimental}

All chemicals used in this study were of reagent grade (Analar, BDH, Sigma). Buffer solutions were prepared from acetic acid and sodium acetate of known concentration. $\mathrm{NaNO}_{3}$ was used to adjust ionic strength in the different buffered solution. Doubly distilled $\mathrm{H}_{2} \mathrm{O}$ was used in all kinetic runs. A stock solution of $\mathrm{NaIO}_{4}$ (Aldrich) was prepared by accurate weighing and wrapped in aluminum foil to avoid photochemical decomposition. ${ }^{25}$

$\mathrm{Na}\left[\mathrm{Cr}^{\mathrm{III}}(\mathrm{DPA})(\mathrm{OX})\left(\mathrm{H}_{2} \mathrm{O}\right)\right] \cdot \mathrm{H}_{2} \mathrm{O}$ was prepared by a method similar to that reported in literature. ${ }^{26}$ Elemental analysis data of the complex was as follows: Found (calcd.) for $\mathrm{Na}\left[\mathrm{Cr}^{\mathrm{III}}(\mathrm{DPA})(\mathrm{OX})\left(\mathrm{H}_{2} \mathrm{O}\right)\right] \cdot \mathrm{H}_{2} \mathrm{O}$, $\left[\mathrm{NaCr}^{\mathrm{III}} \mathrm{C}_{9} \mathrm{H}_{8} \mathrm{O}_{10} \mathrm{~N}\right] ; \mathrm{C}, 28.93$ (29.58); H, 2.32 (2.19); $\mathrm{N}, 3.67(3.84) \%$. In the IR spectrum of the complex, the band at $3555 \mathrm{~cm}^{-1}$ was assigned to $v(\mathrm{OH})$ of lattice water, while the bands at 3471 and $911 \mathrm{~cm}^{-1}$ are attributed to $v(\mathrm{OH})$ of the coordinated water molecule. ${ }^{27}$ The carboxylate band $v(\mathrm{COO})$ was observed at $1647 \mathrm{~cm}^{-1}$, indicating that the deprotonated carboxylic groups of the ligands are coordinated to the chromium ion. The thermogram of $\left[\mathrm{NaCr}^{\mathrm{III}} \mathrm{C}_{9} \mathrm{H}_{8} \mathrm{O}_{10} \mathrm{~N}\right]$ shows a weight loss $(9.34 \%)$ beginning at $196.6^{\circ} \mathrm{C}$ corresponding to the loss of one lattice water and one coordinated water molecule (calc. 9.86\%). The weight loss $(19.28 \%)$ at $379.5^{\circ} \mathrm{C}$ corresponds to the loss of one $\mathrm{CO}_{2}$ and one $\mathrm{CO}$ molecule (calc. 19.73\%). The elemental analysis, IR spectrum and thermogram of $\left[\mathrm{NaCr}^{\mathrm{III}} \mathrm{C}_{9} \mathrm{H}_{8} \mathrm{O}_{10} \mathrm{~N}\right]$ complex thus agree with the structure formula as shown in figure 1 .

UV-visible absorption spectra of the products of oxidation of $\left[\mathrm{Cr}^{\text {III }}(\mathrm{DPA})(\mathrm{OX})\left(\mathrm{H}_{2} \mathrm{O}\right)\right]^{-}$by $\mathrm{IO}_{4}^{-}$were followed spectrophotometrically for a definite period of time using the LABOMED, INC UVD-2960 spectrophotometer. All reactants were thermally equilibrated for ca $15 \mathrm{~min}$ in an automatic circulation thermostat, thoroughly mixed and quickly transferred to an absorption cell. Oxidation rates were measured by monitoring the absorbance of $\mathrm{Cr}^{\mathrm{VI}}$ at $355 \mathrm{~nm}$, on a Perkin Elmer EZ-150 spectrophotometer, where absorption of the oxidation products is maximal at the reaction $\mathrm{pH}$.

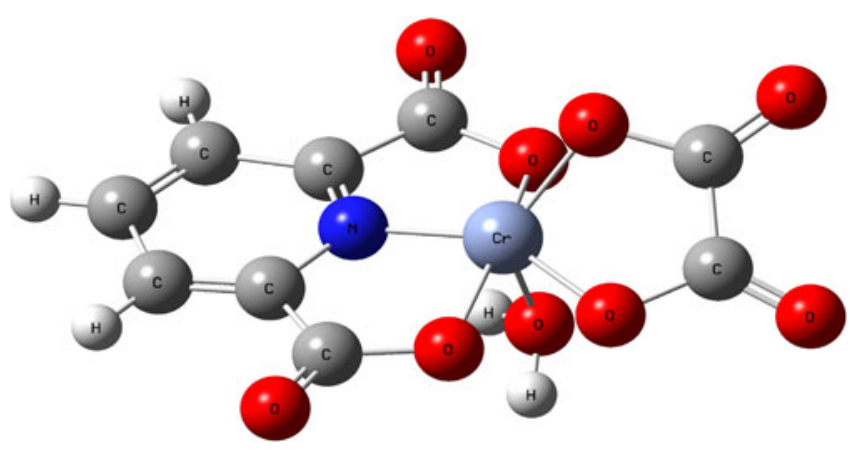

Figure 1. Structure formula of chromium(III) complex. 
The $\mathrm{pH}$ of the reaction mixture was measured using ATC pH-meter G353. Temperature of the reacting solution was controlled, using automatic circulation thermostat. A thermostat was provided with a special pumping system for circulating water at regulated temperature in the cell holder. Average stabilizing accuracy as measured in the thermostat liquid was $\pm 0.1^{\circ} \mathrm{C}$

Pseudo-first-order conditions were maintained in all runs by the presence of a large excess ( $>10$-fold) of $\mathrm{IO}_{4}^{-}$. The ionic strength was kept constant by addition of $\mathrm{NaNO}_{3}$ solution. The $\mathrm{pH}$ of the reaction mixture was found to be constant during the reaction run. Pseudo-first-order rate constants, $k_{\text {obs }}$, were obtained from the slopes of plots of $\ln \left(A_{\infty}-A_{\mathrm{t}}\right)$ versus time, where $A_{\mathrm{t}}$ and $A_{\infty}$ are the absorbances at time $t$ and infinity, respectively. The enthalpy of activation, $\Delta H^{*}$, and entropy of activation $\Delta S^{*}$, were calculated using the Eyring equation by plotting $\ln (k / T)$ against $1 / T$;

$$
\ln k / T=\ln k_{b} / h+\Delta S^{*} / R-\Delta H^{*} / R T,
$$

where: $k_{b}$ is the Boltzmann constant, $h$ is Plank's constant, $R$ is the universal gas constant, $T$ is the absolute temperature and $k$ is the rate constant. Error limits for the results were calculated using Microcal $^{\mathrm{TM}}$ Origin ${ }^{\circledR}$ (Version 7.0).

Stoichiometry of the reaction was determined by measuring the absorbance of $\mathrm{Cr}^{\mathrm{VI}}$ produced at $355 \mathrm{~nm}$ after $24 \mathrm{~h}$ from the onset of the reaction using excess concentration of complex over that of $\mathrm{IO}_{4}^{-}$. Quantity of $\mathrm{Cr}^{\mathrm{III}}$ consumed was calculated using molar absorptivity of $\mathrm{Cr}^{\mathrm{VI}}$ at the employed $\mathrm{pH}$.

In order to verify the presence of free radicals in the reaction, the following test was performed. A reaction mixture containing acrylonitrile was kept for $24 \mathrm{~h}$ in an inert atmosphere. On diluting the reaction mixture with methanol, no precipitate was formed; hence, this suggests that there is no possibility of free radical intervention in the reaction.

\section{Results and discussion}

Ultraviolet visible absorption spectra of the oxidation products of $\left[\mathrm{Cr}^{\mathrm{III}}(\mathrm{DPA})(\mathrm{OX})\left(\mathrm{H}_{2} \mathrm{O}\right)\right]^{-}$are shown in figure 2. Absorption spectra of this reaction were monitored as a function of time over the $300-700 \mathrm{~nm}$ range. Absorption spectra show that the chromium(III)complex peaks at 560 and $412 \mathrm{~nm}$ have disappeared and are replaced by an other peak at $355 \mathrm{~nm}$ which corresponds to chromium(VI). This is identical to periodate oxidations of some chromium(III) complexes under the same conditions. ${ }^{18-20}$ Presence of a isosbestic point at $500 \mathrm{~nm}$ in the absorption spectra was taken as the

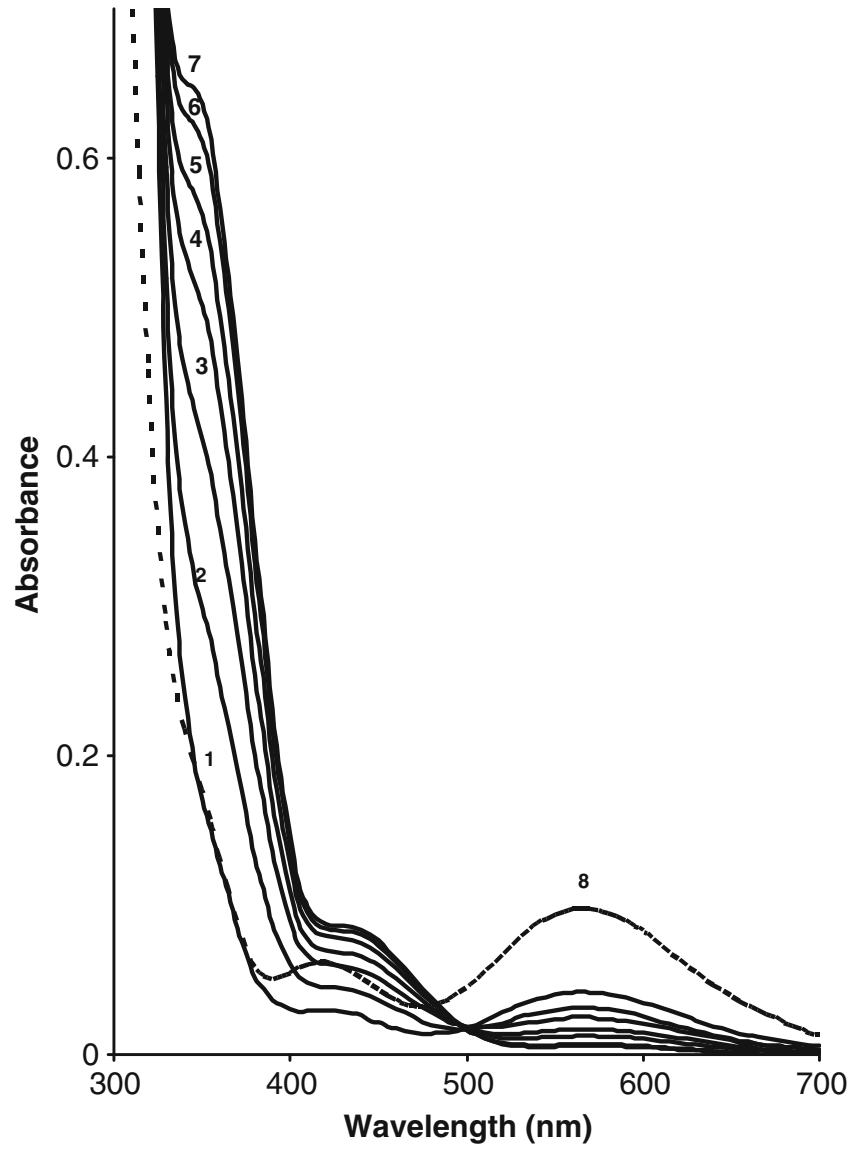

Figure 2. Change in absorbance as a function of time: Curves (1)-(7) were recorded at 5, 10, 15, 20, 25, 30 and $40 \mathrm{~min}$, respectively from the time initiation: [complex] $=$ $5.0 \times 10^{-4} \mathrm{~mol} \mathrm{dm}{ }^{-3},\left[\mathrm{IO}_{4}^{-}\right]=0.02 \mathrm{~mol} \mathrm{dm}^{-3}, I=$ $0.20 \mathrm{~mol} \mathrm{dm}^{-3}\left(\mathrm{NaNO}_{3}\right), \mathrm{pH}=4.99$ and $\mathrm{T}=30^{\circ} \mathrm{C}$. Curve (8) spectrum of $\mathrm{Cr}^{\mathrm{III}}$-complex $=1.0 \times 10^{-3} \mathrm{~mol} \mathrm{dm}^{-3}$.

criterion for the presence of two absorbing species in equilibrium.

The kinetics of oxidation of $\left[\mathrm{Cr}^{\mathrm{III}}(\mathrm{DPA})(\mathrm{OX})\left(\mathrm{H}_{2} \mathrm{O}\right)\right]^{-}$ by periodate were studied over the $4.45-5.57 \mathrm{pH}$ range, $0.20 \mathrm{~mol} \mathrm{dm}^{-3}$ ionic strength, $(0.50-5.0) \times 10^{-2} \mathrm{~mol}$ $\mathrm{dm}^{-3}$ periodate concentration range, $(1.25-6.25) \times$ $10^{-4} \mathrm{~mol} \mathrm{dm}^{-3}$ complex concentration range, and 20.0$40.0^{\circ} \mathrm{C}$.

Stoichiometry of the $\left[\mathrm{Cr}^{\mathrm{III}}(\mathrm{DPA})(\mathrm{OX})\left(\mathrm{H}_{2} \mathrm{O}\right)\right]^{-} / \mathrm{IO}_{4}^{-}$ reaction can be represented by equation (1).

$2 \mathrm{Cr}^{\mathrm{III}}+3\left[\mathrm{IO}_{4}\right]^{-} \longrightarrow 2 \mathrm{Cr}^{\mathrm{VI}}+3\left[\mathrm{IO}_{3}\right]^{-}+\mathrm{DPA}+\mathrm{OX}$.

The ratio of $\left[\mathrm{IO}_{4}\right]^{-}$initially present to $\mathrm{Cr}^{\mathrm{VI}}$ produced was $1.5 \pm 0.03$, the stoichiometry is consistent with the observation that $\mathrm{IO}_{3}^{-}$does not oxidize the $\mathrm{Cr}^{\mathrm{III}}$ complex over the $\mathrm{pH}$ range where the kinetics was investigated.

Plots of $\ln \left(A_{\infty}-A_{\mathrm{t}}\right)$ versus time were linear up to $>85 \%$ from the beginning of reaction where $A_{\mathrm{t}}$ and 
$A_{\infty}$ are absorbance at time $t$ and infinity, respectively. Pseudo-first-order rate constants, $k_{\text {obs }}$, were obtained from the slopes of these plots, thus values of $10^{5} k_{\mathrm{obs}}$ of $5.88 \pm 0.02,6.27 \pm 0.04,6.39 \pm 0.03$ and $6.21 \pm$ $0.05 \mathrm{~s}^{-1}$ were obtained at $10^{-4}\left[\mathrm{Cr}^{\mathrm{III}}(\mathrm{DPA})(\mathrm{OX})\left(\mathrm{H}_{2} \mathrm{O}\right)^{-}\right]=$ $2.50,3.75,6.25$ and $7.50 \mathrm{~mol} \mathrm{dm}{ }^{-3}, \mathrm{pH}=4.99$, $\left[\mathrm{IO}_{4}^{-}\right]=0.02 \mathrm{~mol} \mathrm{dm}{ }^{-3}$ and $T=25^{\circ} \mathrm{C}$. These results show that $k_{\text {obs }}$ was unaffected when the concentration of the chromium(III)-complex was varied at constant periodate concentration, indicating first-order dependence on complex concentration.

$$
d\left[\mathrm{Cr}^{\mathrm{VI}}\right] / d t=k_{\mathrm{obs}}\left[\mathrm{Cr}^{\mathrm{III}}\right]_{T},
$$

where $\left[\mathrm{Cr}^{\mathrm{III}}\right]_{T}$ represents the total chromium(III) concentration present. Variation of $k_{\mathrm{obs}}$ with $\left[\mathrm{IO}_{4}^{-}\right]$at various $\mathrm{pH}$ values and different temperatures (table 1), shows that the reaction rate increased as the $\mathrm{pH}$ increased over the range studied under constant reaction conditions. It is obvious from these results that $k_{\text {obs }}$ does not vary linearly with $\left[\mathrm{IO}_{4}^{-}\right]$as in equation (3) at all $\mathrm{pH}$ ranges covered in this study. Actually, the variation with $\left[\mathrm{IO}_{4}^{-}\right]$is very small indicating high association between the two reactants. Plots of $1 / k_{\mathrm{obs}}$ versus $1 /\left[\mathrm{IO}_{4}^{-}\right]$are linear at several $\mathrm{pH}$ values with slopes $(1 / a)$ and an intercepts $(b / a)$ according to linear equation: $y=m x+c$ with correlation coefficients summarized in table 2. Data in table 2 shows that both intercepts $(1 / a)$ and slopes $(b / a)$ are $\mathrm{pH}$-dependent.

$$
k_{\mathrm{obs}}=a\left[\mathrm{IO}_{4}^{-}\right] /\left(1+b\left[\mathrm{IO}_{4}^{-}\right]\right) .
$$

Table 1. Dependence of the rate constant, $10^{5} k_{\mathrm{obs}} \mathrm{s}^{-1}$, on $\left[\mathrm{IO}_{4}^{-}\right]$at different $\mathrm{pHs}$ and

\begin{tabular}{|c|c|c|c|c|c|}
\hline $\mathrm{pH}$ & $\begin{array}{l}10^{2}\left[\mathrm{IO}_{4}^{-}\right] \\
\mathrm{mol} \mathrm{dm}\end{array}$ & $20^{\circ} \mathrm{C}$ & $25^{\circ} \mathrm{C}$ & $30^{\circ} \mathrm{C}$ & $40^{\circ} \mathrm{C}$ \\
\hline \multirow[t]{7}{*}{4.45} & 0.5 & $0.97 \pm 0.01$ & $1.22 \pm 0.02$ & $1.43 \pm 0.01$ & $2.24 \pm 0.03$ \\
\hline & 1.0 & $1.64 \pm 0.01$ & $1.97 \pm 0.01$ & $2.23 \pm 0.01$ & $3.82 \pm 0.01$ \\
\hline & 1.5 & $2.20 \pm 0.02$ & $2.75 \pm 0.02$ & $3.17 \pm 0.04$ & $4.72 \pm 0.02$ \\
\hline & 2.0 & $2.67 \pm 0.01$ & $3.12 \pm 0.05$ & $3.90 \pm 0.02$ & $5.50 \pm 0.06$ \\
\hline & 3.0 & $3.30 \pm 0.03$ & $4.27 \pm 0.03$ & $4.86 \pm 0.05$ & $6.67 \pm 0.04$ \\
\hline & 4.0 & $3.71 \pm 0.02$ & $4.98 \pm 0.02$ & $5.47 \pm 0.03$ & $7.38 \pm 0.04$ \\
\hline & 5.0 & $4.16 \pm 0.04$ & $5.18 \pm 0.04$ & $6.04 \pm 0.02$ & $7.61 \pm 0.05$ \\
\hline \multirow[t]{7}{*}{4.69} & 0.5 & $1.46 \pm 0.01$ & $1.72 \pm 0.01$ & $2.25 \pm 0.03$ & $3.16 \pm 0.03$ \\
\hline & 1.0 & $2.39 \pm 0.02$ & $2.89 \pm 0.01$ & $3.42 \pm 0.01$ & $5.33 \pm 0.03$ \\
\hline & 1.5 & $3.04 \pm 0.05$ & $3.71 \pm 0.04$ & $4.19 \pm 0.05$ & $6.25 \pm 0.03$ \\
\hline & 2.0 & $3.74 \pm 0.03$ & $4.20 \pm 0.02$ & $5.53 \pm 0.03$ & $7.32 \pm 0.03$ \\
\hline & 3.0 & $4.47 \pm 0.02$ & $5.64 \pm 0.03$ & $7.05 \pm 0.04$ & $8.67 \pm 0.05$ \\
\hline & 4.0 & $5.23 \pm 0.02$ & $6.74 \pm 0.03$ & $7.74 \pm 0.03$ & $10.83 \pm 0.04$ \\
\hline & 5.0 & $6.03 \pm 0.04$ & $7.48 \pm 0.06$ & $8.60 \pm 0.06$ & $11.67 \pm 0.05$ \\
\hline \multirow[t]{7}{*}{4.99} & 0.5 & $1.86 \pm 0.01$ & $2.29 \pm 0.02$ & $2.98 \pm 0.02$ & $4.51 \pm 0.02$ \\
\hline & 1.0 & $3.12 \pm 0.02$ & $3.83 \pm 0.04$ & $4.69 \pm 0.02$ & $7.64 \pm 0.04$ \\
\hline & 1.5 & $3.90 \pm 0.05$ & $4.73 \pm 0.02$ & $5.97 \pm 0.05$ & $9.16 \pm 0.07$ \\
\hline & 2.0 & $4.71 \pm 0.03$ & $6.17 \pm 0.03$ & $7.46 \pm 0.05$ & $10.37 \pm 0.05$ \\
\hline & 3.0 & $5.74 \pm 0.04$ & $7.67 \pm 0.06$ & $9.12 \pm 0.04$ & $11.77 \pm 0.06$ \\
\hline & 4.0 & $6.46 \pm 0.07$ & $8.65 \pm 0.04$ & $10.06 \pm 0.07$ & $13.53 \pm 0.10$ \\
\hline & 5.0 & $7.65 \pm 0.03$ & $9.83 \pm 0.05$ & $11.65 \pm 0.06$ & $15.56 \pm 0.15$ \\
\hline \multirow[t]{7}{*}{5.23} & 0.5 & $2.51 \pm 0.02$ & $3.01 \pm 0.01$ & $4.37 \pm 0.03$ & $6.57 \pm 0.08$ \\
\hline & 1.0 & $3.69 \pm 0.01$ & $5.15 \pm 0.04$ & $6.82 \pm 0.03$ & $9.32 \pm 0.06$ \\
\hline & 1.5 & $4.93 \pm 0.01$ & $6.40 \pm 0.05$ & $8.19 \pm 0.05$ & $12.61 \pm 0.06$ \\
\hline & 2.0 & $6.62 \pm 0.04$ & $7.59 \pm 0.03$ & $10.06 \pm 0.07$ & $15.25 \pm 0.09$ \\
\hline & 3.0 & $7.53 \pm 0.03$ & $8.65 \pm 0.03$ & $11.56 \pm 0.07$ & $18.47 \pm 0.012$ \\
\hline & 4.0 & $8.47 \pm 0.05$ & $10.73 \pm 0.07$ & $13.64 \pm 0.10$ & $20.53 \pm 0.07$ \\
\hline & 5.0 & $9.05 \pm 0.04$ & $11.52 \pm 0.05$ & $15.70 \pm 0.08$ & $22.76 \pm 0.09$ \\
\hline \multirow[t]{7}{*}{5.57} & 0.5 & $3.15 \pm 0.01$ & $4.10 \pm 0.03$ & $5.88 \pm 0.02$ & $8.33 \pm 0.12$ \\
\hline & 1.0 & $4.78 \pm 0.02$ & $6.33 \pm 0.02$ & $8.32 \pm 0.04$ & $12.65 \pm 0.015$ \\
\hline & 1.5 & $6.15 \pm 0.03$ & $7.98 \pm 0.04$ & $10.47 \pm 0.04$ & $15.46 \pm 0.20$ \\
\hline & 2.0 & $7.25 \pm 0.04$ & $9.60 \pm 0.03$ & $13.79 \pm 0.06$ & $17.38 \pm 0.14$ \\
\hline & 3.0 & $8.76 \pm 0.06$ & $11.22 \pm 0.08$ & $17.01 \pm 0.09$ & $22.00 \pm 0.20$ \\
\hline & 4.0 & $9.80 \pm 0.03$ & $13.37 \pm 0.06$ & $18.34 \pm 0.08$ & $25.67 \pm 0.25$ \\
\hline & 5.0 & $11.16 \pm 0.05$ & $15.63 \pm 0.06$ & $20.37 \pm 0.12$ & $27.12 \pm 0.15$ \\
\hline
\end{tabular}
temperatures. $\left[\mathrm{Cr}^{\mathrm{III}}(\mathrm{DPA})(\mathrm{OX})\left(\mathrm{H}_{2} \mathrm{O}\right)^{-}\right]=5.0 \times 10^{-4} \mathrm{~mol} \mathrm{dm}^{-3}, I=0.2 \mathrm{~mol} \mathrm{dm}^{-3}$. 
Table 2. Values of intercepts and slopes at various temperatures and $\mathrm{pH}$.

\begin{tabular}{lcccc}
\hline Temp. $\left({ }^{\circ} \mathrm{C}\right)$ & $\mathrm{pH}$ & $r$ & $10^{-3} \mathrm{~b} / a(\mathrm{~s})$ & $10^{-2} 1 / a\left(\mathrm{~mol} \mathrm{dm}^{-3} \mathrm{~s}\right)$ \\
\hline 20.0 & 4.45 & 0.9995 & $15.85 \pm 0.7$ & $4.42 \pm 0.07$ \\
& 4.69 & 0.9966 & $12.48 \pm 0.80$ & $2.84 \pm 0.04$ \\
& 4.99 & 0.9976 & $9.88 \pm 0.65$ & $2.21 \pm 0.05$ \\
& 5.23 & 0.9871 & $8.17 \pm 0.50$ & $1.64 \pm 0.01$ \\
25.0 & 5.57 & 0.9928 & $7.32 \pm 0.45$ & $1.25 \pm 0.02$ \\
& 4.45 & 0.9950 & $12.73 \pm 0.60$ & $3.53 \pm 0.06$ \\
& 4.69 & 0.9951 & $9.68 \pm 0.34$ & $2.46 \pm 0.03$ \\
& 4.99 & 0.9956 & $7.15 \pm 0.50$ & $1.86 \pm 0.02$ \\
30.0 & 5.23 & 0.9976 & $6.38 \pm 0.40$ & $1.34 \pm 0.03$ \\
& 5.57 & 0.9905 & $5.37 \pm 0.22$ & $0.98 \pm 0.03$ \\
& 4.45 & 0.9926 & $11.42 \pm 0.43$ & $3.01 \pm 0.02$ \\
& 4.69 & 0.9855 & $8.97 \pm 0.65$ & $1.86 \pm 0.04$ \\
40.0 & 4.99 & 0.9938 & $6.61 \pm 0.30$ & $1.38 \pm 0.01$ \\
& 5.23 & 0.9906 & $5.40 \pm 0.22$ & $0.89 \pm 0.02$ \\
& 5.57 & 0.9870 & $4.33 \pm 0.34$ & $0.68 \pm 0.03$ \\
& 4.45 & 0.9990 & $9.28 \pm 0.40$ & $1.76 \pm 0.04$ \\
& 4.69 & 0.9927 & $6.80 \pm 0.50$ & $1.25 \pm 0.05$ \\
& 4.99 & 0.9953 & $5.17 \pm 0.20$ & $0.84 \pm 0.01$ \\
& 5.23 & 0.9830 & $3.57 \pm 0.15$ & $0.61 \pm 0.02$ \\
& 5.57 & 0.9897 & $3.080 \pm 0.20$ & $0.46 \pm 0.02$ \\
\hline
\end{tabular}

or

$$
1 / k_{\mathrm{obs}}=1 / a\left[\mathrm{IO}_{4}^{-}\right]+b / a .
$$

Values of $1 / a$ and $b / a$ at different $\mathrm{pH}$ values and different temperatures are represented in table 2. Plots of both $1 / a$ and $b / a$ versus $\left[\mathrm{H}^{+}\right]$are linear as shown in figures 3

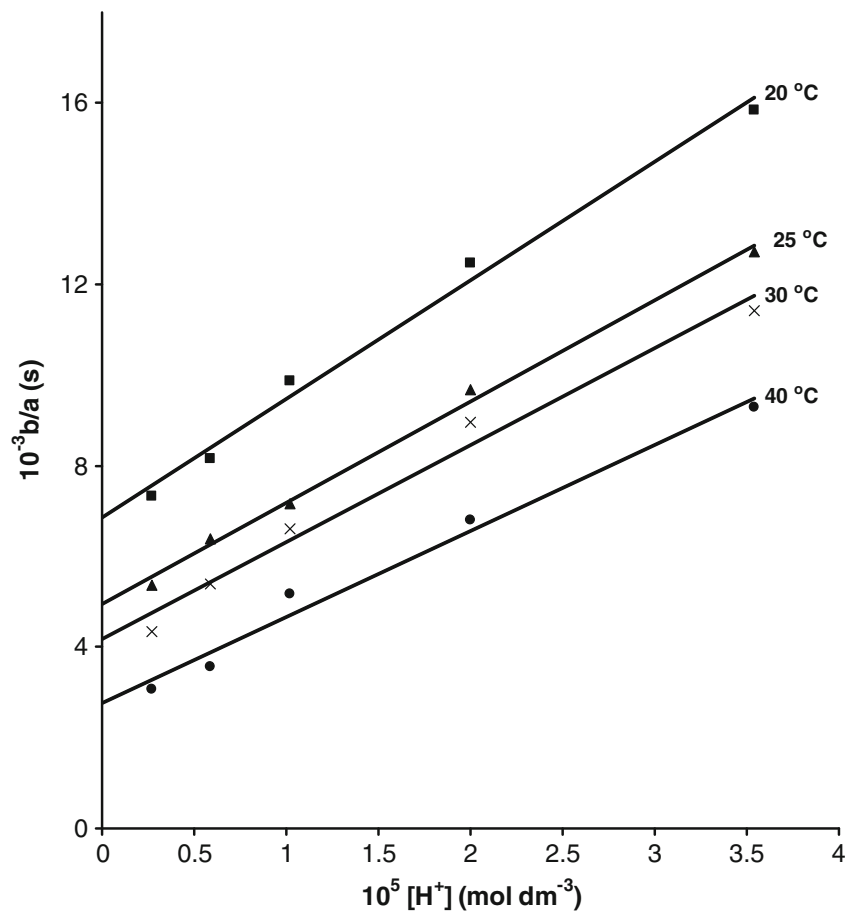

Figure 3. Plot of $b / a$ versus $\left[\mathrm{H}^{+}\right]$at different temperatures. and 4 . It can be seen that this variation is described by equations (5) and (6).

$$
\begin{aligned}
& 1 / a=k_{1}[\mathrm{H}+]+k_{2} . \\
& b / a=k_{3}\left[\mathrm{H}^{+}\right]+k_{4} .
\end{aligned}
$$

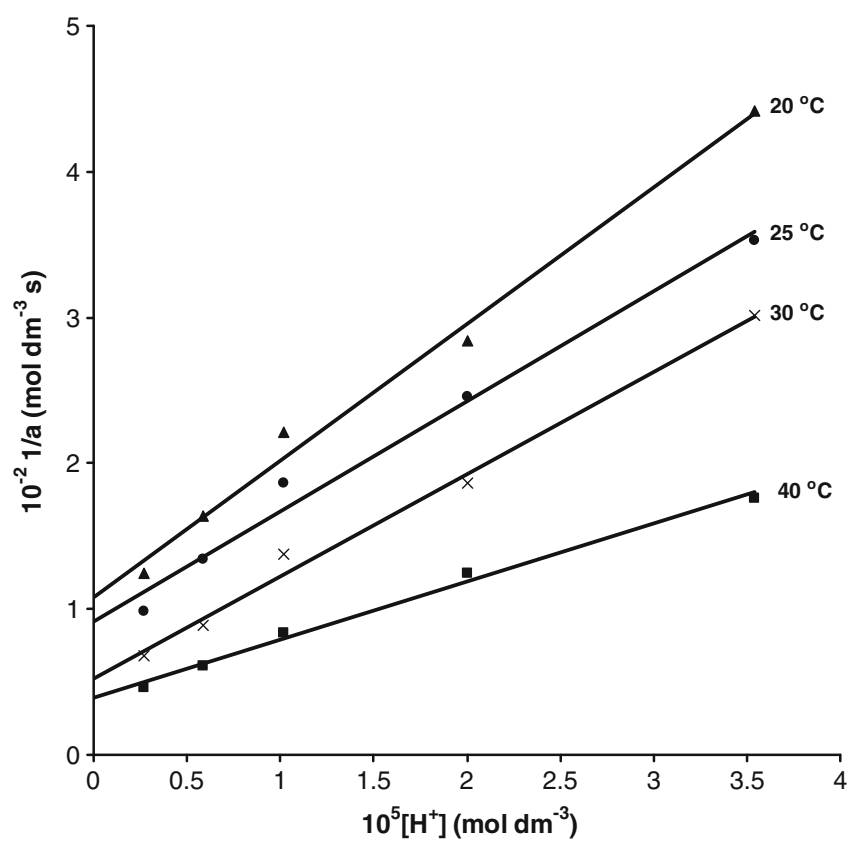

Figure 4. Plot of $1 / a$ versus $\left[\mathrm{H}^{+}\right]$at different temperatures. 
Table 3. Values of $k_{1}, k_{2}, k_{3}$ and $k_{4}$ at different temperatures.

\begin{tabular}{lcrcc}
\hline Temp. $\left({ }^{\circ} \mathrm{C}\right)$ & $10^{-6} k_{1}\left(\mathrm{~mol} \mathrm{dm}^{-3} \mathrm{~s}\right)$ & $10^{-1} k_{2}(\mathrm{~s})$ & $10^{-8} k_{3}\left(\mathrm{~mol}^{-1} \mathrm{dm}^{3} \mathrm{~s}\right)$ & $10^{-3} k_{4}(\mathrm{~s})$ \\
\hline 20 & $9.37 \pm 0.15$ & $10.83 \pm 0.28$ & $2.61 \pm 0.40$ & $6.86 \pm 0.90$ \\
25 & $7.57 \pm 0.08$ & $9.09 \pm 0.15$ & $2.34 \pm 0.50$ & $4.94 \pm 1.00$ \\
30 & $6.99 \pm 0.17$ & $5.26 \pm 0.32$ & $2.14 \pm 0.35$ & $4.17 \pm 0.68$ \\
40 & $3.96 \pm 0.14$ & $3.95 \pm 0.30$ & $1.90 \pm 0.20$ & $2.76 \pm 0.40$ \\
\hline
\end{tabular}

Values of $k_{1}, k_{2}, k_{3}$ and $k_{4}$ were calculated from the intercepts and slopes of figures 3 and 4 and summarized in table 3. Including equations (4), (5) and (6), kinetics of the oxidation of $\left[\mathrm{Cr}^{\mathrm{III}}(\mathrm{DPA})(\mathrm{OX})\left(\mathrm{H}_{2} \mathrm{O}\right)\right]^{-}$by $\mathrm{IO}_{4}^{-}$are given by equation (7).

$$
1 / k_{\mathrm{obs}}=\left(k_{1}+k_{2}\left[\mathrm{H}^{+}\right]\right) /\left[\mathrm{IO}_{4}^{-}\right]+\left(k_{3}+k_{4}\left[\mathrm{H}^{+}\right]\right) .
$$

Also, the rate of reaction increases with increasing ionic strength, thus values of $10^{5} k_{\text {obs }}$ of $6.71 \pm 0.03$, $7.60 \pm 0.05,8.43 \pm 0.04$ and $9.55 \pm 0.07 \mathrm{~s}^{-1}$ were obtained at $I=0.30,0.40,0.50$ and $0.60 \mathrm{~mol} \mathrm{dm}^{-3}$, $\mathrm{pH}=4.99,\left[\mathrm{IO}_{4}^{-}\right]=0.02 \mathrm{~mol} \mathrm{dm}{ }^{-3}$ and $T=25^{\circ} \mathrm{C}$. This phenomenon has been attributed to the fact that the reaction takes place between charged species of the same sign.

Oxidation of $\left[\mathrm{Cr}^{\mathrm{III}}(\mathrm{DPA})(\mathrm{OX})\left(\mathrm{H}_{2} \mathrm{O}\right)\right]^{-}$by periodate may be proceeding through an inner-sphere mechanism. Assignment of an inner-sphere mechanism for this reaction seems to be supported by the fact that $\left[\mathrm{IO}_{4}\right]^{-}$is capable of acting as a ligand as demonstrated by its coordination by copper(III) ${ }^{28}$ and nickel(IV), ${ }^{29}$ in which the coordinated $\mathrm{H}_{2} \mathrm{O}$ is substituted by III ${ }^{18-20}$

Also, it may be concluded that from the reported equilibrium constants of aqueous periodate solutions over the $\mathrm{pH}$ range used, periodate sources likely to be present are $\mathrm{IO}_{4}^{-}, \mathrm{H}_{4} \mathrm{IO}_{6}^{-}$and $\mathrm{H}_{3} \mathrm{IO}_{6}{ }^{2-30}$ according to the following equilibria: ${ }^{30}$

$$
\begin{gathered}
\mathrm{H}_{5} \mathrm{IO}_{6} \rightleftharpoons \mathrm{H}_{4} \mathrm{IO}_{6}^{-}+\mathrm{H}^{+}\left(K_{1}=5.1 \times 10^{-4}\right) \\
\mathrm{H}_{4} \mathrm{IO}_{6}^{-} \rightleftharpoons 2 \mathrm{H}_{2} \mathrm{O}+\mathrm{IO}_{4}^{-}\left(K_{2}=40\right) \\
\mathrm{H}_{4} \mathrm{IO}_{6}^{-} \rightleftharpoons \mathrm{H}_{3} \mathrm{IO}_{6}^{2-}+\mathrm{H}^{+} \quad\left(K_{3}=2.0 \times 10^{-7}\right)
\end{gathered}
$$

From the $K_{3}$ value, $\mathrm{H}_{3} \mathrm{IO}_{6}^{2-}$ is not predominant species (periodate will be used to represent $\mathrm{H}_{4} \mathrm{IO}_{6}^{-}$). ${ }^{30}$

In acid medium, the chromium(III)-complex is in equilibrium:

$$
\left[\mathrm{Cr}^{\mathrm{III}}(\mathrm{DPA})(\mathrm{OX})\left(\mathrm{H}_{2} \mathrm{O}\right)\right]^{-} \rightleftharpoons\left[\mathrm{Cr}^{\mathrm{III}}(\mathrm{DPA})(\mathrm{OX})(\mathrm{OH})\right]^{2-}+\mathrm{H}^{+} \quad K_{4}
$$

$K_{4}$ was measured potentiometrically and has the value of $3.67 \times 10^{-6}$ at $25^{\circ} \mathrm{C}$ and $I=0.20 \mathrm{~mol} \mathrm{dm}^{-3}$. From the $\mathrm{pH}(4.45-5.57)$ and the $K_{4}$ value, it is clear that $\left[\mathrm{Cr}^{\mathrm{III}}(\mathrm{DPA})(\mathrm{OX})(\mathrm{OH})\right]^{2-}$ may be the reactive species. Oxidation rate increases with increasing $\mathrm{pH}$ (table 1 ). This is in agreement with the involvement of the deprotonated form of the complex, $\left[\mathrm{Cr}^{\mathrm{III}}(\mathrm{DPA})(\mathrm{OX})(\mathrm{OH})\right]^{2-}$, in the rate-determining step. An inner-sphere process may still be accommodated through replacement of the $\mathrm{H}_{2} \mathrm{O}$ ligand in $\left[\mathrm{Cr}^{\mathrm{III}}(\mathrm{DPA})(\mathrm{OX})\left(\mathrm{H}_{2} \mathrm{O}\right)\right]^{-}$by $\mathrm{IO}_{4}^{-} \cdot{ }^{19,20}$ An inner-sphere mechanism seems to be preferable if not the only pathway in periodate oxidation. Failure of periodate to oxidize $\mathrm{Fe}(\mathrm{Phen})_{3}^{2+}$ to $\mathrm{Fe}(\mathrm{Phen})_{3}^{3+}$ is in keeping with an inner-sphere mechanism. ${ }^{31}$ Oxidation of $\left[\mathrm{Cr}^{\mathrm{III}}(\mathrm{DPA})(\mathrm{OX})\left(\mathrm{H}_{2} \mathrm{O}\right)\right]^{-}$by periodate may proceed through an inner-sphere mechanism via one or two electron transfer giving chromium(IV) or chromium(V), respectively in the rate-determining step leading to chromium(VI). Two-electron transfer is the most likely pathway and leads to the formation of chromium(V). ${ }^{15,21}$ This seems to be supported by the absence of polymerization with acrylonitrile. If the reaction proceeds via one electron transfer giving chromium(IV), then I(VI) would be formed and polymerization of acrylonitrile occurs. In the oxidation of $\left[\mathrm{Fe}^{\mathrm{II}}\left(\mathrm{H}_{2} \mathrm{O}\right)_{6}\right]^{2+}$ by $\mathrm{IO}_{4}^{-}$, which proceeds by one electron transfer, polymerization of acrylonitrile was observed. ${ }^{32}$

A possible mechanism is described by equations (12-15):

$$
\begin{array}{cc}
{\left[\mathrm{Cr}^{\mathrm{III}}(\mathrm{DPA})(\mathrm{OX})\left(\mathrm{H}_{2} \mathrm{O}\right)\right]^{-}+\left[\mathrm{IO}_{4}^{-}\right] \rightleftharpoons\left[\mathrm{Cr}^{\mathrm{III}}(\mathrm{DPA})(\mathrm{OX})\left(\mathrm{OIO}_{3}\right)\right]^{2-}+\mathrm{H}_{2} \mathrm{O}} & K_{5} \\
{\left[\mathrm{Cr}^{\mathrm{III}}(\mathrm{DPA})(\mathrm{OX})(\mathrm{OH})\right]^{2-}+\left[\mathrm{IO}_{4}^{-}\right] \rightleftharpoons\left[\mathrm{Cr}^{\mathrm{III}}(\mathrm{DPA})(\mathrm{OX})(\mathrm{OH})\left(\mathrm{OIO}_{3}\right)\right]^{3-}} & K_{6}
\end{array}
$$




$$
\begin{gathered}
{\left[\mathrm{Cr}^{\mathrm{III}}(\mathrm{DPA})(\mathrm{OX})\left(\mathrm{OIO}_{3}\right)\right]^{2-} \longrightarrow\left[\mathrm{Cr}^{\mathrm{V}}(\mathrm{DPA})(\mathrm{OX}) \mathrm{O}^{-}+\mathrm{IO}_{3}^{-}+\right.} \\
{\left[\mathrm{Cr}^{\mathrm{III}}(\mathrm{DPA})(\mathrm{OX})(\mathrm{OH})\left(\mathrm{OIO}_{3}\right)\right]^{3-} \longrightarrow\left[\mathrm{Cr}^{\mathrm{V}}(\mathrm{DPA})(\mathrm{OX}) \mathrm{O}^{-}+\mathrm{IO}_{3}^{-}+\mathrm{OH}^{-} k_{6}\right.} \\
{\left[\mathrm{Cr}^{\mathrm{V}}(\mathrm{DPA})(\mathrm{OX}) \mathrm{O}^{-}+\mathrm{IO}_{4}^{-} \longrightarrow \mathrm{Cr}(\mathrm{VI})+\mathrm{IO}_{3}^{-}+\mathrm{DPA}+\mathrm{OX} \quad\right. \text { (fast) }} \\
2 \mathrm{I}^{\mathrm{VI}} \longrightarrow \mathrm{I}^{\mathrm{VII}}+\mathrm{I}^{\mathrm{V}} \text { (fast). }
\end{gathered}
$$

From the above mechanism, the rate of the reaction is given by:

$$
\begin{aligned}
d\left[\mathrm{Cr}^{\mathrm{VI}}\right] / d t= & {\left[\mathrm{Cr}^{\mathrm{III}}(\mathrm{DPA})(\mathrm{OX})\left(\mathrm{H}_{2} \mathrm{O}\right)^{-}\right]\left[\mathrm{IO}_{4}^{-}\right] } \\
& \times\left(k_{5} K_{5}+k_{6} K_{4} K_{6} /\left[\mathrm{H}^{+}\right]\right) .
\end{aligned}
$$

If we assume that $\left[\mathrm{Cr}^{\mathrm{III}}\right]_{T}$ represents all the different forms of chromium(III), then:

$$
\begin{aligned}
& {\left[\mathrm{Cr}^{\mathrm{III}}\right]_{T}=} {\left[\mathrm{Cr}^{\mathrm{III}}(\mathrm{DPA})(\mathrm{OX})\left(\mathrm{H}_{2} \mathrm{O}\right)^{-}\right] } \\
&+\left[\mathrm{Cr}^{\mathrm{III}}(\mathrm{DPA})(\mathrm{OX})(\mathrm{OH})^{2-}\right] \\
&+\left[\mathrm{Cr}^{\mathrm{III}}(\mathrm{DPA})(\mathrm{OX})\left(\mathrm{OIO}_{3}\right)^{2-}\right] \\
&+\left[\mathrm{Cr}^{\mathrm{III}}(\mathrm{DPA})(\mathrm{OX})(\mathrm{OH})\left(\mathrm{OIO}_{3}\right)^{3-}\right] \\
& {\left[\mathrm{Cr}^{\mathrm{III}}\right]_{T}=\left[\mathrm{Cr}{ }^{\mathrm{III}}(\mathrm{DPA})(\mathrm{OX})\left(\mathrm{H}_{2} \mathrm{O}\right)^{-}\right] } \\
& \times\left\{\left(\left[\mathrm{H}^{+}\right]+K_{4}\right)+\left(K_{5}\left[\mathrm{H}^{+}\right]+K_{6} K_{4}\right)\left[\mathrm{IO}_{4}^{-}\right]\right\} .
\end{aligned}
$$

Substituting $\left[\mathrm{Cr}^{\mathrm{III}}(\mathrm{DPA})(\mathrm{OX})\left(\mathrm{H}_{2} \mathrm{O}\right)^{-}\right]$from equation (20) into equation (18) gives:

$$
\begin{aligned}
d\left[\mathrm{Cr}^{\mathrm{VI}}\right] / d t= & {\left[\mathrm{IO}_{4}^{-}\right]\left[\mathrm{Cr}^{\mathrm{III}}\right]_{T}\left(k_{5} K_{5}+k_{6} K_{4} K_{6} /\left[\mathrm{H}^{+}\right]\right) / } \\
& \left\{\left(\left[\mathrm{H}^{+}\right]+K_{4}\right)+\left(K_{5}\left[\mathrm{H}^{+}\right]+K_{6} K_{4}\right)\left[\mathrm{IO}_{4}^{-}\right]\right\}
\end{aligned}
$$

Hence,

$$
\begin{aligned}
k_{\mathrm{obs}}= & {\left[\mathrm{IO}_{4}^{-}\right]\left(k_{5} K_{5}+k_{6} K_{4} K_{6} /\left[\mathrm{H}^{+}\right]\right) / } \\
& \left\{\left(\left[\mathrm{H}^{+}\right]+K_{4}\right)+\left(K_{5}\left[\mathrm{H}^{+}\right]+K_{6} K_{4}\right)\left[\mathrm{IO}_{4}^{-}\right]\right\} .
\end{aligned}
$$

Since, deprotonated form, $\left[\mathrm{Cr}^{\mathrm{III}}(\mathrm{DPA})(\mathrm{OX})(\mathrm{OH})\right]^{2-}$ is considered to be more reactive form than its conjugate acid, we can assume $K_{6}>>K_{5}$ and that equation (22) may be reduced to equation (23).

$$
\begin{aligned}
k_{\mathrm{obs}}= & k_{6} K_{4} K_{6}\left[\mathrm{IO}_{4}^{-}\right] /\left\{\left(\left[\mathrm{H}^{+}\right]+K_{4}\right)\right. \\
& \left.+\left(K_{5}\left[\mathrm{H}^{+}\right]+K_{6} K_{4}\right)\left[\mathrm{IO}_{4}^{-}\right]\right\} .
\end{aligned}
$$

Upon rearrangement:

$$
\begin{aligned}
1 / k_{\mathrm{obs}}= & 1 /\left[\mathrm{IO}_{4}^{-}\right]\left\{\left[\mathrm{H}^{+}\right] / k_{6} K_{4} K_{6}+1 / k_{6} K_{6}\right\} \\
& +\left\{K_{5}\left[\mathrm{H}^{+}\right] / k_{6} K_{4} K_{6}+1 / k_{6}\right\}
\end{aligned}
$$

From equation (24), the slope (1/a) and intercept (b/a) are given by equations (25) and (26), respectively.

$$
\begin{aligned}
& 1 / a=\left[\mathrm{H}^{+}\right] / k_{6} K_{4} K_{6}+1 / k_{6} K_{6} \\
& b / a=K_{5}\left[\mathrm{H}^{+}\right] / k_{6} K_{4} K_{6}+1 / k_{6} \\
& k_{1}=1 / k_{6} K_{4} K_{6} ; k_{2}=1 / k_{6} K_{6} ; \\
& k_{3}=K_{5} / k_{6} K_{4} K_{6} ; k_{4}=1 / k_{6}
\end{aligned}
$$

The $K_{4}$ value was calculated by dividing $k_{2} / k_{1}$, as $1.20 \times 10^{-5} \mathrm{~mol} \mathrm{dm}^{-3}$ at $25^{\circ} \mathrm{C}$. Values of $K_{5}$ and $K_{6}$ were calculated from $k_{3} / k_{1}$ and $k_{4} / k_{2}$ as 30.91 and $54.34 \mathrm{~mol}^{-1} \mathrm{dm}^{3}$ at $25^{\circ} \mathrm{C}$, respectively. The intramolecular electron transfer rate constant, $k_{5}$, was calculated at different temperatures from $k_{4}=1 / k_{6}$ as follows: $10^{4} k_{6}=1.46,2.02,2.40$ and $3.62 \mathrm{~s}^{-1}$ at $20,25,30$ and $40^{\circ} \mathrm{C}$, respectively. From the previous data, it is clear that the electron transfer rate constant, $k_{6}$, increases with increasing temperature. Thermodynamic activation parameters including the enthalpy and entropy terms associated with $k_{6}$ were calculated from a leastsquares fit to the transition state theory equation as $\Delta H^{*}$ $31.0 \pm 2.6 \mathrm{~kJ} \mathrm{~mol}^{-1}$ and $\Delta S^{*}-211.7 \pm 8.5 \mathrm{~J} \mathrm{~K}^{-1} \mathrm{~mol}^{-1}$, respectively.

High negative entropies of activation for this reaction may result from the charge concentration on encounter complex formation, which causes substantial mutual ordering of the solvated water molecules. ${ }^{33}$ Intramolecular electron transfer steps are endothermic as indicated by the positive $\Delta H^{*}$ values. Contributions of $\Delta H^{*}$ and $\Delta S^{*}$ to the rate constant seem to compensate each other. This fact suggests that the factors controlling $\Delta H^{*}$ must be closely related to those controlling $\Delta S^{*}$. Therefore, the solvation state of the encounter complex would be important in determining $\Delta H^{*} .{ }^{33}$ The relatively low value of enthalpy of activation, $\Delta H^{*}$, can be explained in terms of the formation of a more solvated complex. 
Table 4. Enthalpies and entropies of activation for the oxidation of some chromium(III) complexes by periodate.

\begin{tabular}{|c|c|c|c|c|c|}
\hline Complex & $10^{3} k^{\mathrm{et}}\left(\mathrm{s}^{-1}\right)$ & $\Delta H^{*}(\mathrm{KJ} / \mathrm{mol})$ & $-\Delta S^{*}(\mathrm{~J} / \mathrm{Kmol})$ & Ref. & Figure 5 key \\
\hline$\left[\mathrm{Cr}^{\mathrm{III}}(\mathrm{TOH})\left(\mathrm{H}_{2} \mathrm{O}\right)\right]$ & 2.95 & $76 \pm 2.1$ & $38.7 \pm 7.1$ & 15 & 1 \\
\hline$\left[\mathrm{Cr}^{\mathrm{III}}(\mathrm{NTA})(\mathrm{Asp})\left(\mathrm{H}_{2} \mathrm{O}\right)\right]^{-}$ & 3.93 & $64.6 \pm 8.5$ & $76 \pm 7.7$ & 22 & 2 \\
\hline$\left[\mathrm{Cr} \text { III }(\mathrm{Ud})(\mathrm{Asp})\left(\mathrm{H}_{2} \mathrm{O}\right)_{3}\right]^{2+}$ & 0.70 & $59.5 \pm 9.2$ & $107 \pm 35.2$ & 21 & 3 \\
\hline$\left[\mathrm{Cr}^{\mathrm{III}}(\mathrm{Ud})\left(\mathrm{H}_{2} \mathrm{O}\right)_{3}\right]^{3+}$ & 9.31 & $37.8 \pm 3.1$ & $158.3 \pm 39.3$ & 21 & 4 \\
\hline$\left[\mathrm{Cr}^{\mathrm{III}}\left(\mathrm{HIDA}(\mathrm{Val})\left(\mathrm{H}_{2} \mathrm{O}\right)\right]\right.$ & 1.22 & $41.7 \pm 1.5$ & $162.5 \pm 3.3$ & 33 & 5 \\
\hline$\left[\mathrm{Cr}^{\mathrm{III}}(\mathrm{DPA})(\mathrm{OX})\left(\mathrm{H}_{2} \mathrm{O}\right)\right]^{-}$ & 0.24 & $31 \pm 2.6$ & $212 \pm 8.5$ & This work & 6 \\
\hline$[\mathrm{Cr}$ & 1.82 & $15.9 \pm 1.2$ & $227 \pm 5$ & 33 & 7 \\
\hline$\left[\mathrm{Cr}^{\mathrm{III}}(\mathrm{HIDA})_{2}\left(\mathrm{H}_{2} \mathrm{O}\right)\right]$ & 10.9 & $12.3 \pm 1$ & $240.7 \pm 7$ & 18 & 8 \\
\hline
\end{tabular}

Enthalpies and entropies of activation for the oxidation of chromium(III) complexes by periodate are shown in table $4 . \Delta H^{*}$ and $\Delta S^{*}$ for the oxidation of these complexes were calculated related to intramolecular electron transfer steps except for $\left[\mathrm{Cr}^{\mathrm{III}}(\mathrm{HIDA})_{2}\left(\mathrm{H}_{2} \mathrm{O}\right)\right],{ }^{18}\left[\mathrm{Cr}^{\mathrm{III}}(\mathrm{HIDA})(\mathrm{Arg})\left(\mathrm{H}_{2} \mathrm{O}\right)_{2}\right]^{+}, 34$ and $\left[\mathrm{Cr}^{\mathrm{III}}(\mathrm{NTA})(\mathrm{Hist})\left(\mathrm{H}_{2} \mathrm{O}\right)\right]^{-},{ }^{22} \Delta H^{*}$ and $\Delta S^{*}$ are composite values including enthalpy of formation of the precursor complexes and intramolecular electron transfer steps. A plot of $\Delta \mathrm{H}^{*}$ versus $\Delta \mathrm{S}^{*}$ for these complexes is shown in figure 5 , and an excellent linear relationship was obtained. Similar linear plots were found for a large number of redox reactions ${ }^{35}$ and for each reaction series, a common rate-determining step is proposed. The isokinetic relation lends support to a common mechanism for the oxidation of chromium(III) complexes, reported here, by periodate. This consists of a periodate ion coordination to the chromium(III) complexes in a step preceding the rate-determining

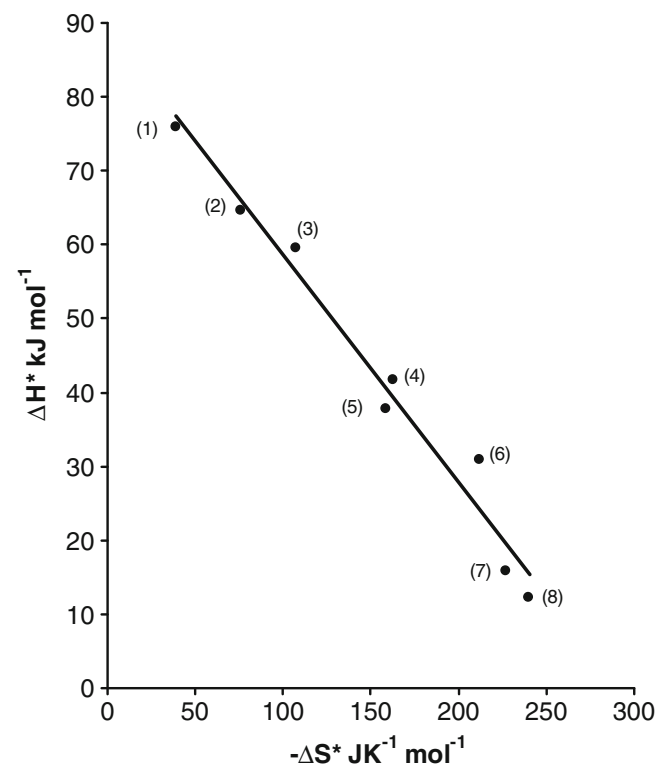

Figure 5. Relation between enthalpies and entropies of activation of some chromium(III) Complexes. intramolecular electron transfer within the precursor complex. Isokinetic compensation between $\Delta H^{*}$ and $\Delta S^{*}$ in a series of related reactions usually implies that one interaction between the reactants varies within the series, the remainder of the mechanism being invariant. ${ }^{36}$ Electron transfer reactivities of these complexes with periodate are comparable, as the coordination of periodate with these complexes are identical. All these suggest that the excellent correlation often observed between $\Delta S^{*}$ and $\Delta H^{*}$ mainly reflects the fact that both thermodynamic parameters are in reality two measures of the same thing, and that measuring a compensation temperature is just a rather indirect way of measuring the average temperature at which the experiments were carried out. As this temperature will often be in a range that the experimenter expects to have some biological significance, it is not surprising if the compensation temperature turns out to have a biologically suggestive value. ${ }^{37}$

\section{Conclusion}

Oxidation of $\left[\mathrm{Cr}^{\mathrm{III}}(\mathrm{DPA})(\mathrm{OX})\left(\mathrm{H}_{2} \mathrm{O}\right)\right]^{-}$by periodate proceeds via an inner-sphere mechanism. Rate of oxidation increases with increase in $\mathrm{pH}$. These reactions proceed through two-electron transfer process leading to the formation of chromium(VI). A common mechanism for the oxidation of ternary chromium(III) complexes by periodate is proposed, and is supported by the excellent isokinetic relationship between $\Delta H^{*}$ and $\Delta S^{*}$ values for these reactions.

\section{Acknowledgements}

This project was funded by the (SABIC) and the Deanship of Scientific Research (DSR), King Abdulaziz University, Jeddah, under grant no. (MS/13/234/1432). The authors, therefore, acknowledge with thanks SABIC and DSR for technical and financial support. 


\section{References}

1. Brzyska W and Ozga W 1997 Polish J. Chem. 714336

2. Ferrora S, Passamont P, Bortocci V and Fucciarelli F 1997 J. Chem. Soc. Faraday Trans. 93289

3. Setlow P 2003 Curr. Opin. Microbiol. 550556

4. Nadai M, Watanabe H, Fujiwara C, Kakegawa H, Sataoh T, Takada J, Matsushita R and Sakurai H 1995 Biol. Pharm. Bull. 18719

5. Anderson R A, Cheng N, Bryden N A, Polansky M M, Cheng N, Chi J and Feng J 1997 Diabetes 461786

6. Yang L, Crans D C, Miller S M, La Cour A, Anderson O P, Kaszynski P M, Godzala M E, Austin L D and Willsky G R 2002 Inorg. Chem. 414859

7. Josiane M, Toloti C, Crisiti D B, Elias Z A and Santos M L 2005 Anal. Chim. Acta 531279

8. Slyke D D V, Hiller A, Macfadyen D A, Hastings A B and Kemperer F W 1994 J. Biol. Chem. 133287

9. Anna D M, Gabriele D and Arduino O 1998 Clin. Chim. Acta 274189

10. Levina A, Codd R, Dillon C T and Lay P A 2003 Prog. Inorg. Chem. $\mathbf{5 1} 145$

11. Levina A and Lay P A 2005 Coord. Chem. Rev. 249281

12. Vincent J B and Latour J M 2003 J. Am. Chem. Soc. 125 774

13. Levina A and Lay P A 2008 Chem. Res. Toxicol. 21563

14. Galliford D J B and Ottaway J M 1972 Analyst 91415

15. Abdel-Khalek A A and Elsmongy M M 1988 Bull. Chem. Soc. Jpn. 614407

16. Ali I H and Sulfab Y 2011 Inter. J. Chem. Kinet. 43563

17. Ewais H A and Muftah S M 2012 J. Oxid. Commun. 35340

18. Hassan H A, Otaibi F D and Abdel-Khalek A A 2006 Inorg. React. Mech. 639
19. Abdel-Hady A M 2000 Trans. Met. Chem. 25437

20. Abdel-Khalek A A, Sayyah S M and Ewais H A 1997 Trans. Met. Chem. 22557

21. Khaled E S H 2007 Inorg. React. Mech. 6247

22. Ewais H A, Elroby S A and Habib M A 2010 Trans. Met. Chem. 3537

23. Ewais H A, Nagdy M A and Abdel-Khalek A A 2012 J. Oxid. Commun. 35327

24. Ewais H A, Nagdy M A and Abdel-Khalek A A 2012 Trans. Met. Chem. 37525

25. Head F S and Standing H A 1953 J. Chem. Soc. 755670

26. Ewais H A 2002 Trans. Met. Chem. 27562

27. Lever A B P 1984 Inorganic electronic spectroscopy (Amsterdam, The Netherlands: Elsevier)

28. Hadince I, Jenovsky L, Linek A and Synecek V 1960 Naturwissenschaften 47377

29. Ray P 1957 Inorg. Synth. 5201

30. Crouthamel C E, Hayes A M and Martin D S 1951 J. Am. Chem. Soc. Jpn. 7382

31. Rizzotto M, Levina A, Santoro M, Garcia S, Frascaroli M I, Signorella S, Sala L F and Lay P A 2002 J. Chem. Soc. Dalt. Trans. 3206

32. Symons M C R 1955 J. Chem. Soc. 2794. doi:10. 1039/JR9550002794

33. Weaver M J and Yee E L 1980 Inorg. Chem. 191936

34. Ewais H A, Dahman F D and Abdel-Khalek A A 2009 Central J. Chem. 33

35. Mcardle J V, Coyle C L, Gray H B, Yoneda C S and Howerda R A 1977 J. Am. Chem. Soc. 992483

36. Wherland S and Gray H B 1977 Biological aspects of inorganic chemistry, D Dolphin (ed.) (New York: Wiley) p. 189

37. Bowden A C 2002 J. Biosci. 27121 